\title{
The influence of HRM practices and employees' satisfaction on intention to leave
}

\section{Mohammad Saud Zamanan ${ }^{a}$, Mohammad Humoud Alkhaldia ${ }^{a}$ Abdullah Sultan Almajroub ${ }^{\text {a }}$, Ab- dulmohsen Salem Alajmi ${ }^{a}$, Jassim Mohammad Alshammari ${ }^{a}$ and Omar Jaber Aburumman ${ }^{b^{*}}$}

${ }^{a}$ Faculty of Business and Finance, The World Islamic Sciences and Education University, Jordan

${ }^{b}$ Faculty of Business, Economics and Social Development, University Malaysia Terengganu, Malaysia

\begin{tabular}{l}
\hline C H R O N I C L E \\
\hline Article history: \\
Received: October 24, 2019 \\
Received in revised format: No- \\
vember 28 2019 \\
Accepted: December 22, 2019 \\
Available online: \\
December 22, 2019 \\
\hline Keywords: \\
HRM Practices \\
Employees Satisfaction \\
Intention to Leave
\end{tabular}

Intention to Leave

\section{A B S T R A C T}

\begin{abstract}
This study aims to examine the influence of HRM practices (employees' empowerment, job security, and employees' participation) and employees' satisfaction on intention to leave and the mediating role of employees' satisfaction from the perspective of faculty members in private universities in Kuwait. The survey questionnaire was gathered from 261 faculty members who were working in four private universities in Kuwait. The study used the software SmartPLS (version 3.2.8) to test the study hypotheses. The findings indicate that HRM practices (employees' empowerment and job security) and employees' satisfaction had negative effects on intention to leave, and employees' satisfaction partially mediated the relationship between HRM practices (employees' empowerment and job security) and intention to leave. Future studies may include other samples as public universities or other sectors in Kuwait such as the education sector or health care sector.
\end{abstract}

\section{Introduction}

Many researchers consider intention to leave or turnover intention as a critical issue for organizations (Shah \& Beh, 2016; Thakur \& Bhatnagar, 2017; Omar et al., 2018; Aburumman et al., 2020). Intention to leave is dependent on many personal and impersonal reasons, a person leaves the job when finds another job easily or has other opportunities, but employees' who leave the organization by their own choice or based on organization desire, both create troubles for the organization, where the organizations bear a loss of investment which they do in training and selection of such employees' (Xu et al., 2018). Therefore, if there is a risk related to employees' intention to leave, it will impact the organization by this big challenge, because the success of an organization highly depends on its employees (Nelissen et al., 2017). There is a need to address the issues related to intention to leave because it is a phenomenon in itself, and it was considered as one of the most challenging issues worldwide (Santhanam et al., 2017). Moreover, the literature that studied HRM practices did not care about practices that are related to the personal aspect of the employees such as employees' empowerment, job security, and employees' participation which could impact employees' intention to leave (Aburumman et al., 2020). Thus, this study aims to search for factors that lead to a decrease the employees' intention to leave by focusing on HRM practices that are related to the personal aspect of the employees namely employees' empowerment, job security, and employees' participation. Table 1 shows the research gap and the extent of the contribution of the current study in the literature related to these variables.

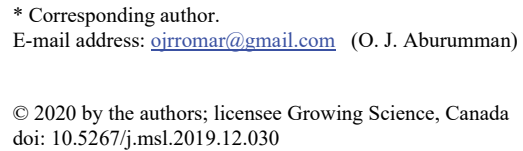


Table 1

Research Gap

\begin{tabular}{|c|c|c|c|c|c|c|c|c|c|c|}
\hline Author/Year & $\begin{array}{c}\text { EE } \\
\text { and } \\
\text { IL }\end{array}$ & $\begin{array}{c}\text { JS } \\
\text { and } \\
\text { IL }\end{array}$ & $\begin{array}{c}\text { EP } \\
\text { and } \\
\text { IL }\end{array}$ & $\begin{array}{c}\text { EE } \\
\text { and } \\
\text { ES }\end{array}$ & $\begin{array}{c}\text { JS } \\
\text { and } \\
\text { ES }\end{array}$ & $\begin{array}{c}\text { EP } \\
\text { and } \\
\text { ES }\end{array}$ & $\begin{array}{c}\text { ES } \\
\text { and } \\
\text { IL }\end{array}$ & $\begin{array}{l}\text { EE, ES } \\
\text { and } I L\end{array}$ & $\begin{array}{l}\text { JS, ES } \\
\text { and IL }\end{array}$ & $\begin{array}{l}\text { EP, ES } \\
\text { and IL }\end{array}$ \\
\hline Joarder $(2011)$ & & $\sqrt{ }$ & & & & & & & & \\
\hline Kim and Fernandez (2017) & $\sqrt{ }$ & & & & & & & & & \\
\hline Chughtai (2013) & $\sqrt{ }$ & & & & & & & & & \\
\hline Zhang et al., (2019) & & $\sqrt{ }$ & & & & & & & & \\
\hline Kumar and Jauhari (2016) & & & $\sqrt{ }$ & & & & & & & \\
\hline Idris et al., (2018) & & & & $\sqrt{ }$ & & & & & & \\
\hline Begum and Mohamed (2016) & & & & & & $\sqrt{ }$ & & & & \\
\hline Imran et al., (2015) & & & & & $\sqrt{ }$ & & & & & \\
\hline Huo and Boxall (2018) & & & & & & $\sqrt{ }$ & & & & \\
\hline Al-Kilani (2017) & & & & & & & $\sqrt{ }$ & & & \\
\hline Lim et al., (2017) & & & & & & & $\sqrt{ }$ & & & \\
\hline Bayarcelik and Findikli (2016) & & & & & & & $\sqrt{ }$ & & & \\
\hline Yukongdi and Shrestha (2020) & & & & & & & $\sqrt{ }$ & & & \\
\hline Current Study & $\sqrt{ }$ & $\sqrt{ }$ & $\sqrt{ }$ & $\sqrt{ }$ & $\sqrt{ }$ & $\sqrt{ }$ & $\sqrt{ }$ & $\sqrt{ }$ & $\sqrt{ }$ & $\sqrt{ }$ \\
\hline
\end{tabular}

Note: EE: Employees Empowerment, JS: Job Security, EP: Employees Participation, ES: Employees Satisfaction, IL: Intention to Leave

\section{Hypotheses Development}

\subsection{HRM Practices and Intention to Leave}

Previous literature showed the significance of employees' empowerment against the intention to leave, by providing the information, delegation and transfer of powers and participate to make decisions to employees' in lower levels in the organization, thus employee will be responsible for the decisions, activities, and behaviors he or she makes (Kim \& Fernandez, 2017). The work environment which is an indicator of poor employees' empowerment has implications for employees' intention to leave (Chughtai, 2013). Job security is a main concern of organizations because it contributes to the limit of many critical issues such as low career loyalty, low trust in management, poor performance, and high employees' intention to leave (Lee \& Jeong, 2017). Moreover, employees' participation in the process of organizational decision-making contributes to an increase in employees' positive behavior such as staying longer at work (Kumar \& Jauhari, 2016), where employees with greater involvement in the decision-making process believe that they are important part in the organization (Gould-Williams, 2007). Therefore, this study proposes the following hypotheses:

H1: There is a negative relationship between employees' empowerment and intention to leave.

H2: There is a negative relationship between job security and intention to leave.

H3: There is a negative relationship between employees' participation and intention to leave.

\subsection{HRM Practices and Employees Satisfaction}

The employees' empowerment with information about performance, job, goals has a significant positive effect on employees' satisfaction (Idris et al., 2018). Contrariwise, if the information is provided in a controlling way, employees' satisfaction will be low (Fernandez \& Moldogaziev, 2015). Studies indicate that employees' have the intention to stay in work only when their organization is providing them satisfaction which can be in the form of job security (Imran et al., 2015). According to Lee (2006) and Begum and Mohamed (2016), employees' participation in the process of problem-solving and decision-making contributes to increased employees' satisfaction, by feeling that they are an important part of the organization. Therefore, this study proposes the following hypotheses:

H4: There is a positive relationship between employees' empowerment and employees' satisfaction.

H5: There is a positive relationship between job security and employees' satisfaction.

H6: There is a positive relationship between employees' participation and employees' satisfaction.

\subsection{Employees Satisfaction and Intention to Leave}

Employees' satisfaction is a significant indicator of employees' intention to leave the work (Egan et al., 2004), while employees who have the intention to stay and not leave their organizations to have a high level of satisfaction for their job (Wright \& Bonett, 2007). Direnzo and Greenhaus (2011) noted that organizations should pay more attention to the level of employees' satisfaction, which could help reduce the intention to leave. Recent studies have revealed that employees' satisfaction is negatively related to employee's intention to leave (Bayarcelik \& Findikli, 2016; Al-Kilani, 2017; Lim et al., 2017; Yukongdi \& Shrestha, 2020). Therefore, this study proposes the following hypothesis:

H7: There is a negative relationship between employees' satisfaction and intention to leave. 


\subsection{HRM Practices, Employees Satisfaction and Intention to Leave}

According to the principle of reciprocity in the social exchange theory (Blau, 1964), Aburumman et al., (2020, p 649) stated that "if organizations provide a positive behavior; the employees will behave similarly and will commit to positive behaviors by staying longer and demonstrating a high commitment and satisfaction". Based on the social exchange theory, this study proposed that employees' empowerment, job security, and employees' participation affect intention to leave through the mediation of employees' satisfaction. Therefore, this study proposes the following hypotheses:

H8: Employees Satisfaction mediates the relationship between employees' empowerment and intention to leave.

H9: Employees Satisfaction mediates the relationship between job security and intention to leave.

H10: Employees Satisfaction mediates the relationship between employees' participation and intention to leave.

Fig. 1 shows the research model of the current study, where the employees' empowerment, job security, and employees' participation are independent variables, employees' satisfaction is mediation variable and intention to leave is the dependent variable.

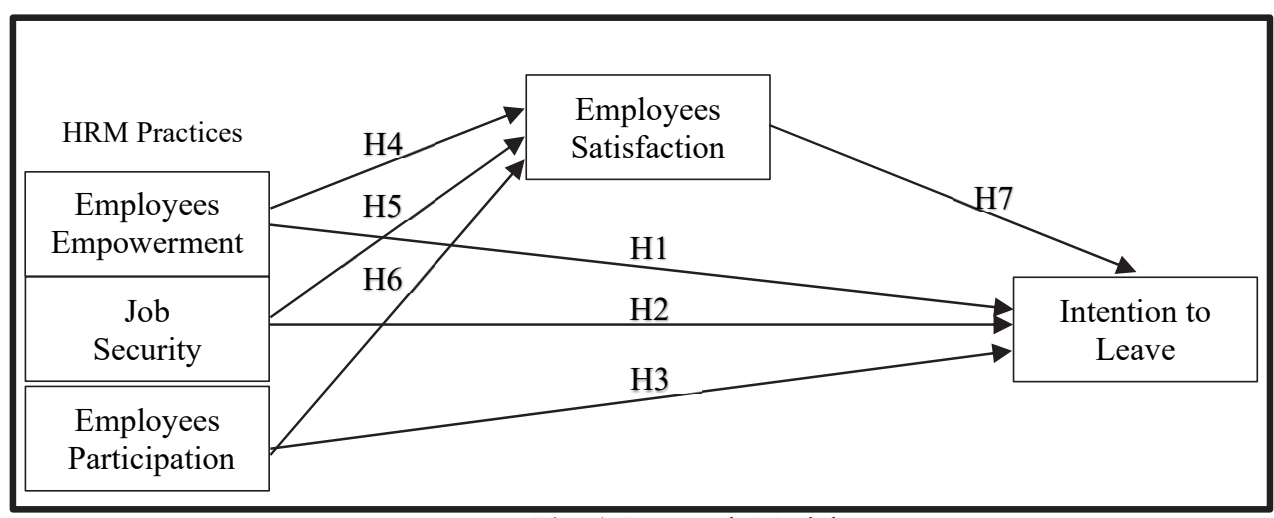

Fig. 1. Research Model

\section{Research Methodology}

\subsection{Research Design and Sample}

This study used a quantitative approach based on a survey questionnaire. The survey included faculty members in private universities in Kuwait namely the American University of Kuwait, Gulf University for Science and Technology, American University of the Middle East and Arab Open University - Kuwait. The current study sample size was 274 faculty members who were working in the previously mentioned universities. The current study used convenience sampling as a strategy for sampling technique because that convenience sampling inexpensive and usually requires less time. The total number of responses was 261 , which represents $95.2 \%$ of the number of distributed questionnaires, and a total of 13 questionnaires were not received.

\subsection{Measurements of Study}

All items were measured using a 5-point Likert scale ranging from 1 "strongly disagree" to 5 "strongly agree". Regarding to measurement of variables, this study considers three HRM practices namely employees' empowerment (five items, e.g. "I feel competent to perform the tasks required for my position"), job security (four items, e.g. "I can stay in the university for as long as I wish"), and employees' participation (four items, e.g. "Employees in this university are allowed to make many decisions"), where that all these items adapted from scale of Delery and Doty (1996) and scale of Hanaysha (2016). Employees' satisfaction was measured using a scale of Blegen et al. (2004) in six items (e.g. "I feel that I am happier in my work than most people"). Intention to leave was measured using a scale of Klassen and Chiu (2011) in three items (e.g. "I intend to leave the teaching profession").

\section{Data Analysis and Results}

The analysis of this study data included two main aspects namely measurement model assessment and structural model assessment. Accurate procedures were followed to prove the validity and reliability of the measurement model by using the software SmartPLS (version 3.2.8), where the measurement model assessment included convergent validity and discriminant validity. Table 2 shows the results of convergent validity, where the results indicate that Cronbach's alpha and composite reliability achieved values greater than the proposed threshold values of 0.60 to 0.70 and above for all variables (Hair et al., 2016). Regarding average variance extracted (AVE), all variables achieved values greater than the proposed threshold value of 0.50 by (Hair et al., 2016). Meanwhile, all the items have loadings ranged from 0.757 to 0.934 except for EE3 and ES6 which have achieved loadings less than 0.4 , thus they were deleted. 
Table 2

Convergent Validity

\begin{tabular}{|c|c|c|c|c|c|}
\hline VARIABLE & Items & Loadings & Cronbach's Alpha & Composite Reliability & AVE \\
\hline \multirow[t]{4}{*}{ Employees Empowerment } & EE1 & 0.903 & 0.925 & 0.946 & 0.815 \\
\hline & EE2 & 0.913 & & & \\
\hline & EE4 & 0.901 & & & \\
\hline & EE5 & 0.894 & & & \\
\hline \multirow[t]{4}{*}{ Job Security } & JS1 & 0.812 & 0.838 & 0.891 & 0.672 \\
\hline & JS2 & 0.872 & & & \\
\hline & JS3 & 0.836 & & & \\
\hline & JS4 & 0.757 & & & \\
\hline \multirow[t]{4}{*}{ Employees Participation } & EP1 & 0.879 & 0.877 & 0.915 & 0.728 \\
\hline & EP2 & 0.870 & & & \\
\hline & EP3 & 0.844 & & & \\
\hline & EP4 & 0.819 & & & \\
\hline \multirow[t]{5}{*}{ Employees Satisfaction } & ES1 & 0.830 & 0.903 & 0.928 & 0.722 \\
\hline & ES2 & 0.888 & & & \\
\hline & ES3 & 0.885 & & & \\
\hline & ES4 & 0.834 & & & \\
\hline & ES5 & 0.807 & & & \\
\hline \multirow[t]{3}{*}{ Intention to Leave } & IL1 & 0.912 & 0.917 & 0.948 & 0.858 \\
\hline & IL2 & 0.933 & & & \\
\hline & IL3 & 0.934 & & & \\
\hline
\end{tabular}

Discriminant validity was analyzed based on the Fornell-Larcker criterion. Table 3 shows the results of the Fornell-Larcker Criterion, where the square root of AVE in bold is higher than the other elements of the row and column in which they are located. According to the assessment of the results of convergent validity and discriminant validity, the measurement model for the current study is valid and reliable.

Table 3

Discriminant Validity Based on Fornell-Larcker Criteria

\begin{tabular}{|c|c|c|c|c|c|}
\hline & Employees Empowerment & $\begin{array}{c}\text { Job } \\
\text { Security }\end{array}$ & $\begin{array}{c}\text { Employees Partic- } \\
\text { ipation }\end{array}$ & $\begin{array}{l}\text { Employees Satis- } \\
\text { faction }\end{array}$ & Intention to Leave \\
\hline Employees Empowerment & 0.903 & & & & \\
\hline Job Security & -0.108 & 0.820 & & & \\
\hline Employees Participation & -0.052 & 0.090 & 0.853 & & \\
\hline Employees Satisfaction & 0.280 & 0.115 & 0.123 & 0.849 & \\
\hline Intention to Leave & -0.221 & -0.270 & -0.152 & -0.652 & 0.926 \\
\hline
\end{tabular}

Regarding the structural model assessment, as shown in Table 4, the value of $\mathrm{R}^{2}$ of employees' satisfaction is at 0.116 (unacceptable), while the value of $\mathrm{R}^{2}$ of intention to leave is at 0.472 (moderate) based on the criterion of Chin (1998). Therefore, the model of intention to leave in this study have predictive power according to the value of $\mathrm{R}^{2}$.

Table 4

$\mathrm{R}^{2}$ Values for the Endogenous Variables

\begin{tabular}{lccc}
\hline Variable & Variable Type & $\mathrm{R}^{2}$ & Predictive Relevance \\
\hline Employees Satisfaction & Endogenous Variable & 0.116 & Unacceptable \\
Intention to Leave & Endogenous Variable & 0.472 & Moderate \\
\hline
\end{tabular}

Furthermore, the test was performed on the hypothesized model using the PLS algorithm embedded with SmartPLS (version 3.2.8). Then, the path coefficients were created (see Fig. 2). Then, bootstrapping techniques embedded with SmartPLS (version 3.2.8) were used to conclude whether the path coefficients are statistically significant or insignificant. Table 5 shows PValues and T-Values accompanying each path coefficient.

Table 5

Results of the Structural Model

\begin{tabular}{|c|c|c|c|c|c|c|}
\hline No. & Hypotheses & Path Coefficient & Standard Error & T-Value & P-Value & Decision \\
\hline H1 & $\mathrm{EE} \rightarrow \mathrm{IL}$ & -0.079 & 0.045 & 1.746 & 0.040 & Supported* \\
\hline H2 & $\mathrm{JS} \rightarrow \mathrm{IL}$ & -0.204 & 0.038 & 5.319 & 0.000 & Supported ${ }^{* * *}$ \\
\hline H3 & $\mathrm{EP} \rightarrow \mathrm{IL}$ & -0.065 & 0.044 & 1.475 & 0.070 & Not Supported \\
\hline H4 & $\mathrm{EE} \rightarrow \mathrm{ES}$ & 0.301 & 0.056 & 5.416 & 0.000 & Supported*** \\
\hline H5 & $\mathrm{JS} \rightarrow \mathrm{ES}$ & 0.136 & 0.050 & 2.739 & 0.003 & Supported** \\
\hline H6 & $\mathrm{EP} \rightarrow \mathrm{ES}$ & 0.126 & 0.057 & 2.222 & 0.013 & Supported* \\
\hline H7 & $\mathrm{ES} \rightarrow \mathrm{IL}$ & -0.598 & 0.048 & 12.485 & 0.000 & Supported*** \\
\hline
\end{tabular}

Note: $* * *: \mathrm{p}<0.001, * *: \mathrm{p}<0.01, *: \mathrm{p}<0.05$ 


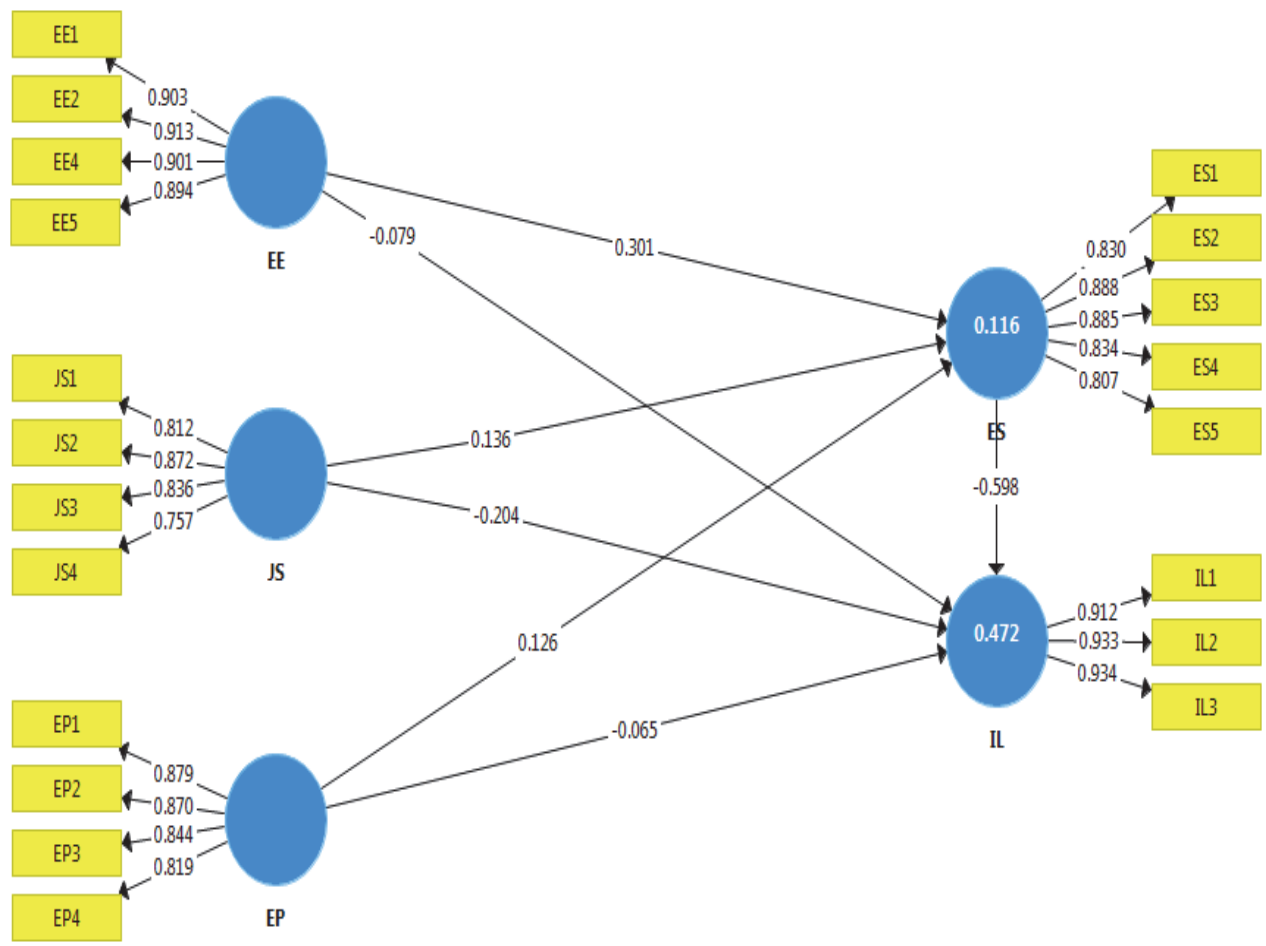

Fig. 2. Path Coefficient and $\mathrm{R}^{2}$ Values for the Research Model

As indicated in Table 5, employees' empowerment had a negative direct effect on intention to leave $(\beta=-0.079$; T-Value $=$ 1.746; P-Value $=0.040$ ), as a result, H1 was supported. This result was consistent with those reported by previous researchers (Chughtai, 2013; Kim \& Fernandez, 2017), who highlighted that work environment which supports employees' empowerment has implications for employees' intention to stay, by providing the information, delegation and transfer of powers and participate to make decisions to employees' in lower levels in the organization, thus employee will be responsible for the decisions, activities, and behaviors he or she makes. The results also indicated that job security had a negative direct effect on intention to leave $(\beta=-0.204 ; \mathrm{T}-$ Value $=5.319 ; \mathrm{P}-$ Value $=0.000)$, as a result, $\mathrm{H} 2$ was supported. This result was consistent with those reported by previous researchers (Joarder, 2013; Lee \& Jeong, 2017), who highlighted that employees' intentions to leave will drop when organizations offer them a stable job opportunity for them. Differently, the results indicated that employees' participation had no direct effect on intention to leave $(\beta=-0.065$; T-Value $=1.475$; P-Value $=0.070)$, as a result, H3 was not supported. On the other hand, employees' participation had an indirect effect on intention to leave by employees' satisfaction fully mediated this relationship (see H10 in Table 6).

According to this result, faculty members feel more satisfied when the university increases their participation with higher levels regarding decision-making and perspectives, generating a positive affective response in the faculty members by staying longer at work. These observations are in line with the results of García-Chas et al. (2014). As indicated in Table 5, employees' empowerment had a positive effect on employees' satisfaction $(\beta=0.301$; T-Value $=5.416$; P-Value $=0.000)$, as a result, H4 was supported. This result was consistent with those reported by previous researchers (Fernandez \& Moldogaziev, 2015; Idris et al., 2018), who highlighted that employees' empowerment with information about performance, job, goals contributes to increasing the level of employees' satisfaction. The results also indicated that job security had a positive effect on employees' satisfaction $(\beta=0.136$; T-Value $=2.739$; P-Value $=0.003)$, as a result, H5 was supported. This result was consistent with those reported by previous researchers (Imran et al., 2015; Wilczyńska et al., 2016), who highlighted that employees' have the intention to stay in work only when their organization is providing them satisfaction which can be in the form of job security. Moreover, the results indicated that employees' participation had a positive effect on employees' satisfaction $(\beta=$ 0.126 ; T-Value $=2.222 ; \mathrm{P}-$ Value $=0.013$ ), as a result, H6 was supported. This result was consistent with those reported by previous researchers (Lee, 2006; Begum \& Mohamed, 2016; Huo \& Boxall, 2018), who highlighted that employees' participation in the process of problem-solving and decision-making contributes to increased employees' satisfaction, by feeling that they are an important part of the organization. Additionally, employees' satisfaction had a negative effect on intention to leave $(\beta=-0.598 ; \mathrm{T}-$ Value $=12.485 ; \mathrm{P}-$ Value $=0.000)$, as a result, $\mathrm{H} 7$ was supported. According to this result, that employees who have a low level of satisfaction will have the intention to leave the job because a low level of satisfaction leads to encouraging employees to search for a new job that has a high level of satisfaction. These observations are in line with the results of previous studies (Bayarcelik \& Findikli, 2016; Al-Kilani, 2017; Lim et al., 2017; Yukongdi \& Shrestha, 2020). 
Table 6

Testing the Mediating Effect of Employees' Satisfaction

\begin{tabular}{|c|c|c|c|c|c|c|c|}
\hline \multirow[t]{2}{*}{ No. } & \multirow[t]{2}{*}{ Hypothesis } & \multirow[t]{2}{*}{ Indirect Effect } & \multirow{2}{*}{$\begin{array}{c}\text { Standard } \\
\text { Error }\end{array}$} & \multirow[t]{2}{*}{ P-value } & \multicolumn{2}{|c|}{ Confidence Interval } & \multirow[t]{2}{*}{ Decision } \\
\hline & & & & & $95 \% \mathrm{LL}$ & $95 \%$ UL & \\
\hline H8 & $\mathrm{EE} \rightarrow \mathrm{ES} \rightarrow \mathrm{IL}$ & -0.180 & 0.036 & 0.000 & -0.240 & -0.120 & Partial Mediation \\
\hline H9 & $\mathrm{JS} \rightarrow \mathrm{ES} \rightarrow \mathrm{IL}$ & -0.082 & 0.030 & 0.004 & -0.129 & -0.028 & Partial Mediation \\
\hline H10 & $\mathrm{EP} \rightarrow \mathrm{ES} \rightarrow \mathrm{IL}$ & -0.075 & 0.034 & 0.014 & -0.126 & -0.014 & Full Mediation \\
\hline
\end{tabular}

Regarding the mediation test for employees' satisfaction, the current study used the method of Preacher and Hayes (2008) for mediation test. As indicated in Table 6, employees' satisfaction mediates the relationship between employees' empowerment and intention to leave (Indirect Effect $=-0.180, \mathrm{P}$-value $=0.000, \mathrm{LL}=-0.240, \mathrm{UL}=-0.120$ ), as a result, H8 was supported and the employees' satisfaction (ES) partially mediated this relationship. The results also indicated that employees' satisfaction mediates the relationship between job security and intention to leave (Indirect Effect $=-0.082, \mathrm{P}$-value $=0.004, \mathrm{LL}=$ $0.129, \mathrm{UL}=-0.028$ ), as a result, H9 was supported and the employees' satisfaction (ES) partially mediated this relationship. Moreover, employees' satisfaction mediates the relationship between employees' participation and intention to leave (Indirect Effect $=-0.075$, P-value $=0.014, \mathrm{LL}=-0.126, \mathrm{UL}=-0.014$ ), as a result, $\mathrm{H} 10$ was supported and the employees' satisfaction (ES) fully mediated this relationship. Social exchange theory which is based on the principle of reciprocity (Blau, 1964) supported these relationships, where if organizations provided a positive behavior (employees' empowerment, job security, and employees' participation), the employees will behave similarly by showing their satisfaction, thus an increased level of employees intention to remain in their work for a long period of time.

\section{Conclusions and Future Directions}

This study has aimed to examine the influence of HRM practices (employees' empowerment, job security, employees' participation) and employees' satisfaction on intention to leave for faculty members in private universities in Kuwait. The results of this study indicate that employees' empowerment, job security, and employees' satisfaction had negative effects on intention to leave. Also, the results indicate that employees' satisfaction partially mediated the relationship between employees' empowerment, job security, and intention to leave. Moreover, the results indicate that employees' satisfaction fully mediated the relationship between employees' participation and intention to leave. HRM must overcome the intention of employees to leave the work, by a focus on these factors because from the perspective of employees that these factors together are the criteria by which maybe employees decide to stay or leave the work. This study was limited to faculty members in private universities in Kuwait as a sample for this study. Future studies may include other samples as public universities or other sectors in Kuwait such as the education sector or health care sector.

\section{Acknowledgement}

The authors would like to thank the anonymous referees for constructive comments on earlier version of this paper.

\section{References}

Aburumman, O., Salleh, A., Omar, K., \& Abadi, M. (2020). The impact of human resource management practices and career satisfaction on employee's turnover intention. Management Science Letters, 10(3), 641-652.

Al-Kilani, M. H. (2017). The influence of organizational justice on intention to leave: examining the mediating role of organizational commitment and job satisfaction. Journal of Management and Strategy, 8(1), 18-27.

Bayarcelik, E. B., \& Findikli, M. A. (2016). The mediating effect of job satisfaction on the relation between organizational justice perception and intention to leave. Procedia-Social and Behavioral Sciences, 235, 403-411.

Begum, F. W., \& Mohamed, D. M. S. (2016). A Study on HRM Practices and its Impact on Job Satisfaction and Organization Performance in BPO Sector, Tiruchirappalli. International Journal of Advanced Research in Management, 7(3), 1-9.

Blau, P. M. (1964). Exchange and power in social life. New York: John Wiley and Sons.

Blegen, M. A., Vaughn, T., Pepper, G., Vojir, C., Stratton, K., Boyd, M., \& Armstrong, G. (2004). Patient and staff safety: voluntary reporting. American Journal of Medical Quality, 19(2), 67-74.

Chin, W. W. (1998). The partial least squares approach to structural equation modeling. Modern methods for business research, 295(2), 295-336.

Chughtai, T. A. (2013). Role of HR practices in turnover intentions with the mediating effect of employee engagement. Wseas Transactions on Business and Economics, 10(2), 97-103.

Delery, J. E., \& Doty, D. H. (1996). Modes of theorizing in strategic human resource management: Tests of universalistic, contingency, and configurational performance predictions. Academy of Management Journal, 39(4), 802-835. 
Direnzo, M. S., \& Greenhaus, J. H. (2011). Job search and voluntary turnover in a boundaryless world: A control theory perspective. Academy of Management Review, 36(3), 567-589.

Egan, T. M., Yang, B., \& Bartlett, K. R. (2004). The effects of organizational learning culture and job satisfaction on motivation to transfer learning and turnover intention. Human Resource Development Quarterly, 15(3), 279-301.

Fernandez, S., \& Moldogaziev, T. (2015). Employee empowerment and job satisfaction in the US Federal Bureaucracy: A self-determination theory perspective. The American Review of Public Administration, 45(4), 375-401.

García-Chas, R., Neira-Fontela, E., \& Castro-Casal, C. (2014). High-performance work system and intention to leave: a mediation model. The International Journal of Human Resource Management, 25(3), 367-389.

Gould-Williams, J. (2007). HR practices, organizational climate and employee outcomes: evaluating social exchange relationships in local government. The International Journal of Human Resource Management, 18(9), 1627-1647.

Hair, J. F., Hult, G. T. M., Ringle, C. M., \& Sarstedt, M. (2016). A Primer on Partial Least Squares Structural Equation Modeling. 2nd Ed. Thousand Oaks: Sage Publications.

Hanaysha, J. (2016). Examining the effects of employee empowerment, teamwork, and employee training on organizational commitment. Procedia-Social and Behavioral Sciences, 229, 298-306.

Huo, M. L., \& Boxall, P. (2018). Instrumental work values and responses to HR practices: A study of job satisfaction in a Chinese manufacturer. Personnel Review, 47(1), 60-73.

Idris, A., See, D., \& Coughlan, P. (2018). Employee empowerment and job satisfaction in urban Malaysia: Connecting the dots with context and organizational change management. Journal of Organizational Change Management, 31(3), 697711.

Imran, R., Majeed, M., \& Ayub, A. (2015). Impact of organizational justice, job security and job satisfaction on organizational productivity. Journal of Economics, Business and Management, 3(9), 840-845.

Joarder, M. H., Sharif, M. Y., \& Ahmmed, K. (2011). Mediating Role of Affective Commitment in HRM Practices and Turnover Intention Relationship: A Study in a Developing Context. Business \& Economics Research Journal, 2(4), 135158.

Kim, S. Y., \& Fernandez, S. (2017). Employee empowerment and turnover intention in the US federal bureaucracy. The American Review of Public Administration, 47(1), 4-22.

Klassen, R. M., \& Chiu, M. M. (2011). The occupational commitment and intention to quit of practicing and pre-service teachers: Influence of self-efficacy, job stress, and teaching context. Contemporary Educational Psychology, 36(2), 114129.

Kumar, M., \& Jauhari, H. (2016). Employee participation and turnover intention: Exploring the explanatory roles of organizational justice and learning goal satisfaction. Journal of Workplace Learning, 28(8), 496-509.

Lee, H. (2006). Impact of the civil service reforms on human resources management and job satisfaction determinants. Arizona State University.

Lee, S. H., \& Jeong, D. Y. (2017). Job insecurity and turnover intention: Organizational commitment as mediator. Social Behavior and Personality: an international journal, 45(4), 529-536.

Lim, A. J. P., Loo, J. T. K., \& Lee, P. H. (2017). The impact of leadership on turnover intention: The mediating role of organizational commitment and job satisfaction. Journal of Applied Structural Equation Modeling, 1(1), $27-41$.

Nelissen, J., Forrier, A., \& Verbruggen, M. (2017). Employee development and voluntary turnover: Testing the employability paradox. Human Resource Management Journal, 27(1), 152-168.

Omar, K., Halim, M. A. S. A., Yusoff, Y. M., Ahmad, A., \& Ibrahim, R. Z. A. R. (2018). Assessing intention to leave among public hospital nurses in Malaysia. Journal of Fundamental and Applied Sciences, 10(3S), 294-305.

Preacher, K. J., \& Hayes, A. F. (2008). Asymptotic and resampling strategies for assessing and comparing indirect effects in multiple mediator models. Behavior Research Methods, 40(3), 879-891.

Santhanam, N., Dyaram, L., \& Ziegler, H. (2017). Impact of human resource management practices on employee turnover intentions: Moderating role of psychological contract breach. Journal of Indian Business Research, 9(3), 212-228.

Shah, S. H. A., \& Beh, L. S. (2016). The impact of motivation enhancing practices and mediating role of talent engagement on turnover intentions: Evidence from Malaysia. International Review of Management and Marketing, 6(4), 823-835.

Thakur, S. J., \& Bhatnagar, J. (2017). Mediator analysis of job embeddedness: Relationship between work-life balance practices and turnover intentions. Employee Relations, 39(5), 718-731.

Wilczyńska, A., Batorski, D., \& Sellens, J. T. (2016). Employment flexibility and job security as determinants of job satisfaction: the case of Polish knowledge workers. Social Indicators Research, 126(2), 633-656.

Wright, T. A., \& Bonett, D. G. (2007). Job satisfaction and psychological well-being as nonadditive predictors of workplace turnover. Journal of Management, 33(2), 141-160.

$\mathrm{Xu}, \mathrm{T} ., \mathrm{Wu}, \mathrm{T} . \mathrm{J} ., \mathrm{L}_{\mathrm{L}}$, Q. Q. (2018). The relationships between job stress and turnover intention among tour guides the moderating role of emotion regulation. Journal of Interdisciplinary Mathematics, 21(2), 409-418.

Yukongdi, V., \& Shrestha, P. (2020). The Influence of Affective Commitment, Job Satisfaction and Job Stress on Turnover Intention: A Study of Nepalese Bank Employees. Review of Integrative Business and Economics Research, 9, 88-98.

Zhang, H., Li, X., Frenkel, S. J., \& Zhang, J. (2019). Human resource practices and migrant workers' turnover intentions: T he roles of post-migration place identity and justice perceptions. Human Resource Management Journal, 29(2), 254-269. 
(C) 2020 by the authors; licensee Growing Science, Canada. This is an open access article distributed under the terms and conditions of the Creative Commons Attribution (CC-BY) license (http://creativecommons.org/licenses/by/4.0/). 